\title{
Attitudinal and Behavioural Loyalty amongst Casino Players in Macau
}

\author{
by \\ Dr. Catherine Prentice \\ Faculty of Business \& Enterprise \\ Swinburne University \\ PO Box 218, Mail H23, John St \\ Hawthorn VIC 3122 Australia \\ Tel: +61 406627622 \\ Email: cathyjournalarticles@ gmail.com
}

\begin{abstract}
Since delivering high quality service tends to improve the loyalty of valued customers, operators should have an understanding of how such customers react to the provision of such experiences. The current investigation was undertaken in Macau casinos and explored the relationship between service quality and customer loyalty, with the latter operationalized on the basis of attitudinal and behavioural dimensions. The researchers used a quantitative method to explore this relationship amongst gamblers characterised by low, medium or high visiting frequency. The segments that were chosen for analysis purposes were consistent with a commonly used approach to segmentation within the survey casinos. Service quality was measured by using a newly developed four dimensional scale (CASERV). The results indicate that service quality explains significant variance in customer loyalty. In particular, service environment and service delivery make substantial contributions to both attitudinal and behavioural loyalty. However, when analysing the relationship separately for VIP and non-VIP players, service quality has minimal influence on the behavioural loyalty of the latter group. Implications of these findings are provided for practitioners and researchers.
\end{abstract}

Key words: casino service quality, behavioural loyalty, attitudinal loyalty, Macau casinos 


\section{Attitudinal and Behavioural Loyalty amongst Casino Players in Macau}

\section{Introduction}

Over recent years numerous casinos have been established in the Asia-Pacific region, and competition has intensified between the various establishments to attract the most lucrative players. As is exemplified by the competitive activities of the various casinos in Macau, the casino industry is transitioning from a traditional monopoly-style model into a more internationalised open market where competition is unpredictable and not necessarily confined to local jurisdictions. Having survived through this fast changing environment, casino marketers have learnt that competitive advantage involves establishing and maintaining good relationships with existing players. The profitability of such strategies has been evidenced by various reports demonstrating positive relationships between player retention rates and profitability (see Kale and Klugsberger, 2007; Watson and Kale, 2003).

Beyond accepting this positive relationship in aggregate terms, it will be an ongoing challenge to optimise the establishment of positive and sustainable customer relationships for both casino practitioners and scholars. Though it has been well established within the relevant academic literature, that service quality is an antecedent of customer loyalty and retention, this has been rarely tested in the casino context. It also remains doubtful whether marketers in Macau casinos are fully aware of the importance of service quality in securing and quantifying player loyalty (see Lam, 2010). Many have shown an over-confidence that players will return unconditionally, perhaps perceiving an absence of alternatives. In the context of a highly dynamic market, casino marketers will need to enhance their awareness of consumer behaviours.

Given the dynamism and competitiveness of the Asia-Pacific casino environment, those who have patronised a particular casino may not remain loyal when competitors are luring them with attractive offerings. It may depend on the nature of their loyalty. Researchers have operationalized customer loyalty into behavioural and attitudinal dimensions (e.g. Dick and Basu, 1994). Whilst behavioural loyalty guarantees shorter run customer retention, positive attitudes (attitudinal loyalty) have connotations of genuine loyalty and long-term profitability for the firm (Kumar and Shah, 2004). In the casino context, it is evident that not all returning casino players have a positive disposition and not all gamblers retain positive attitudes. Players who return may either be genuinely loyal to the casino, or spuriously loyal, because of situational factors such as locational constraints on choice, or positive experiences of winning. Attitudinal loyalty (sometimes described as behavioural intentions) may determine loyalty more accurately than behaviours (Phillips, 
Tandoh, Noble and Bush, 2004). Attitudinal indicators may assist casino marketers to separate those who patronise the establishment for reasons of genuine affinity, from those who visit because of availability and convenience. Personal circumstances such as experiencing a series of losses may hamper the return visitation of previously well-disposed players, and changed financial circumstances may constrain their subsequent gaming activities. However the more positively disposed clients will generate word-of-mouth communication and provide referrals. These customers will retain their commitment to the casino and prospective profitability on the basis of their behavioural indicators. Though building attitudinal loyalty is important for competitive advantage, most forms are also seeking shorter-term benefits which are often manifested by customer behavioural loyalty. Understanding the prospective short- and longer-term effects might assist casino marketers with their decision making and strategy development. In light of these considerations the present study has adopted two-dimensional loyalty to analyse the influence of casino service quality.

Prentice, King and Ohtsuka (2012) recently employed a qualitative approach to investigate how players in a large Asian casino perceive the provision of casino services and how such perceptions influence their attitudinal loyalty. Although the study provided helpful insights into these dimensions, a purely qualitative study cannot provide a holistic picture of player loyalty. Drawing on the findings of the earlier research, the present investigation adopts a quantitative approach to examine the relationship between casino service quality and customer loyalty by incorporating a combination of attitudinal and behavioural dimensions. The relationship between the two dimensions of customer loyalty will be examined. The quantified variance in the criterion variable may prompt casino marketers to review the effectiveness of their current loyalty programs and develop more appropriate marketing strategies in order to stimulate loyalty amongst their customers. It also provides those researching service quality with new perspectives on the relationship.

\section{A brief review of the service quality literature}

Service quality involves customer perceptions of an entity's overall excellence or superiority, through a comparative assessment of expectations and perceived performance (Parasuraman, Zeithaml, and Berry, 1988). Commonly acknowledged as an antecedent of customer satisfaction, service quality in turn drives customer loyalty and company profitability. Researchers have shown that service quality impacts directly on customer 
behavioural intentions and that improved service quality enhances favourable intentions (e.g. Zeithaml, Berry and Parasuraman, 1996). Despite the extensive discussion within the relevant literature about service quality and its associated consequences, there has been limited research on the relationship between service quality and customer retention within the casino context. On the basis that customer preferences are key drivers of viability within the casino industry and that adopting a supply-led philosophy of "build it and they will come" will no longer be effective, gaming researchers, consultants and practitioners have repeatedly noted the importance of service provision as a means of gaining competitive and sustainable advantage in the casino sector (Baird, 2002; Kale, 2006; Johnson, 2002; Stutz, 2008). Delivering quality service is widely regarded as an effective relationship marketing tool for attracting patronage and maintaining customer loyalty. On this basis, it is expected that casino service quality will significantly influence customer loyalty.

A review of the marketing literature reveals that most studies of service quality have viewed the construct as uni-dimensional, or as a means of conveying the overall quality of a firm through the delivery of high quality services. Other researchers (e.g. Brady and Cronin, 2001; Parasuraman, Zeithaml and Berry, 1985; 1988) have asserted that service quality is multi-dimensional and that attempting to use a one-dimensional approach is simplistic. For instance, Parasuraman et al. $(1988,1991)$ have proposed the conceptualisation of service quality as a five dimensional construct consisting of tangibles, reliability, responsiveness, assurance and empathy; whereas others such as Rust and Oliver (1994) and Brady and Cronin (2001) have proposed a model of service quality made up of three components, namely service delivery, service environment and service product. The so-called "Nordic Model" of service quality (i.e. Gronroos, 1984) views services as consisting of both a functional component (the service delivery process) and a technical component (the outcomes).

It is evident that most assessments of service quality acknowledge that the tangible and intangible aspects are complementary. Tangibles refer to the physical elements of a service, whereas the intangibles focus on employees. For instance, of the five dimensions associated with SERVQUAL, tangibles describe physical representations of the service and the appearance of the personnel. The other dimensions focus on the depiction of interpersonal interactions between customers and service representatives. Reliability refers to the accuracy demonstrated by employees in the performance of their duties; responsiveness to their promptness; assurance to trust and empathy to individual attention (see Parasuraman et al., 1988). In the case of highly interactive services where there is no exchange of tangible goods, customer perceptions of service quality arise from an accumulation of personal interactions 
with frontline employees in service encounters (Chandon, Leo and Philippe, 1997). The negotiations and communications that are associated with such interactions will influence subsequent customer attitudes, intentions and behaviours. In the case of more tangible services such as restaurants, technical aspects may play a leading role in shaping perceptions of service quality.

Like many organisations offering service oriented "products" casino services combine tangibility and intangibility. The tangible dimension includes physical facilities and gaming products such as games and slot machines, whereas the intangible refers largely to the services provided by frontline employees generally and by casino hosts in particular. Casinos typically offer a variety of tangible inducements to attract and retain players, particularly in the case of high rollers. Casino managers go to extreme lengths to accommodate the needs and wants of such players. Examples include distributing lavish gifts and redesigning hotel rooms to suit their preferences and idiosyncrasies (see Kale, 2005). However, Prentice et al. (2012) qualitative study reported that such tangible offerings have minimal influence on their loyalty to the casino; whereas a complimentary meal voucher or discounted hotel rates may suffice to prompt low-end players to return to the casino. Since the sample that was used in the earlier qualitative study was small, the findings may not be generalizable. The present paper extends the earlier investigation by adopting a quantitative approach to investigate the relationships.

\section{Methodology}

The research questions within the current study will be addressed most effectively in a casino setting where the operators are confronting a competitive environment and where providing high quality service is critical to gaining competitive advantage. Consistent with these considerations, the survey was conducted in Macau casinos that are operating in such an environment. Casinos in Macau are confronting intensified competition with participation of various international known operators. A questionnaire-based survey focused on the relationship between perceptions of service quality and customer loyalty, and the interrelationship between attitudinal and behavioural loyalty.

To understand the quality-loyalty relationship in casino settings, prospective respondents were recruited from various casinos including Venetian, Wynn, Grand Lisboa and Galaxies in Macau with a view to obtaining a sample that accommodated all relevant target audiences and was generalizable. These casinos have designated various rooms within the gaming area catering for different types of gamblers including tourists and regular low- 
end players; for medium-volume players; and for high rollers. Each room provides players with an area for resting and dining outside their playing periods. The survey was conducted at the non-gaming areas and questionnaires were administered to customers who were having a break from playing.

\section{Measures}

Service quality The literature has proposed various alternative approaches to measuring service quality. Since the present study was conducted in casinos within Macau, the researchers have adopted an instrument which was explicitly designed to measure casino service quality by using a sample of Asian players in Macau - Wong and Fong's (2011) 12item CASERV. CASERV is a refinement of the service quality model originally proposed by Rust and Oliver (1994) and assesses four facets of casino service offerings: game service, service environment, food service and service delivery. Game service represents the technical aspect of a service encounter, such as casino table games and slot machines. The approach aligns with Gronroos' (1984) concept of technical quality and with Rust and Oliver's (1994) core or actual services. Consistent with the concept of servicescape, then expression service environment refers to the atmosphere and physical dimensions of the casino (Bitner, 1992). Service delivery mainly depicts the service performance and behaviours of casino frontline employees and their interactions with customers. It has been widely attested that food plays a key role in the delivery of hospitality services (Ha and Jang, 2010, cited from Wong and Fong, 2011). A rigorous development and validation process involving the conduct of three separate studies was adopted to determine the empirical scale that is used in the case of CASERV. This process resulted in good validities and reliability. The scale also offers the advantage of having been developed on the basis of an Asia-Pacific sample. It was selected as the preferred approach for the conduct of the current study for the reasons noted above. A five point likert-type scale was used to measure CASERV, with 1 = strongly disagree; and 5 $=$ strongly agree. Higher scores are indicative of more positive perceptions of casino service quality. In the present study the applicable Cronbach's alpha values for these dimensions are respectively: .75 (for game service), .74 (for service environment), .89 (for service delivery), and .72 (for food service).

Attitudinal loyalty Zeithaml et al.’s (1996) Behavioural-Intentions Battery (BIB) was used to measure customer attitudinal loyalty. The original BIB is a 13-item scale which measures five behavioural dimensions, namely; Loyalty, Switch, Pay More, External Response, and Internal Response. The researchers reviewed these items in consultation with senior marketing executives based at the survey casinos and ultimately adapted five items to 
suit the purposes and context of the present study. Participants were asked to indicate their likelihood ( 1 = very unlikely; 5 = very likely) of saying positive things about the casino and recommending it to others. Higher scores are indicative of more favourable behavioural intentions. The Cronbach's Alpha coefficient for this adapted scale is .81.

Behavioural loyalty Customer behavioural loyalty was measured on the basis of frequency of annual customer visitation. This was consistent with the approach adopted by most casinos to measure customer loyalty. Since the customer cohort consisted of different betting volume gamblers, the casinos use differential scales to measure their loyalty by dividing the gamblers into VIP and non-VIP players based on their average betting volume. We categorised players into high frequency visitors (HFVs), medium frequent visitors (MFVs), and low frequency visitors (LFVs) based on the criteria that casinos use to rank player visiting frequency. These categories were recoded into a three - point Likert-type scale for each group $(1=$ least frequent, representing LFVs, $3=$ most frequent, representing HFVs).

\section{Data collection}

The quantitative survey was undertaken during non-playing periods in casino areas where players recuperate and have refreshments. The investigation did not extend to nongaming areas since the study focusses on customers who participate in gaming-related activities. In order to generate a proportionate and adequate sample from each casino, the survey was administered in a variety of casinos within Macau. Prior to commencing the survey, the researchers informed prospective respondents about the purpose of the investigation, and expressed a determination to find means of enhancing the provision of customer services. Respondents were asked to provide consent for their participation and were assured of anonymity. The researchers offered respondents a small gift as a means of providing encouragement to complete the survey.

In total 411 completed and usable questionnaires were returned to the researchers, amounting to $82.20 \%$ of the 500 surveys that were distributed. Of the total usable sample, $250(60.82 \%)$ were male, and 161 (39.19\%) were female. Most customers were over 25 years old, married and in full-time employment. A majority were either self-employed or held quite senior positions (e.g. management or supervisory). Almost 58 per cent of the respondents had a college education and over 55 per cent earned in excess of $\$ 50 \mathrm{k}$ per annum. More than half of the respondents were the Mainland residents and most of the others from Hong Kong. The original survey was translated to Chinese by professional translater. 


\section{Analysis and results}

\section{Means, Standard Deviations and Correlations}

The means, standard deviations, zero order correlations and Cronbach Alpha coefficients are presented in Table 1. All of the relevant scales demonstrated good internal consistency, on the basis that an alpha of .70 is the minimum acceptable level (Nunnally and Bernstein, 1994). The Pearson Correlation coefficients revealed that the four dimensions of CASERV had a significant association with customer loyalty.

\section{Insert Table 1 about here}

Multiple regressions were used to test the relationship between service quality and customer loyalty, with the two dimensions of loyalty serving as the dependent variable and the four CASERV dimensions as independent variables. The results from the multiple regression analysis are presented in Table 2. These indicate that the four factors of CASERV explained 42 and 34 per cent of the variance in customer attitudinal and behavioural loyalty respectively at $\mathrm{p}<.0005$. These figures confirm that the result arising from the regression model was statistically significant. A review of the coefficients table indicates that two of the CASERV factors contributed significantly to both dimensions of customer loyalty- service environment and service delivery. The respective scores were $\beta=.32, t=2.18, p<.001$ and $\beta=.46, t=$ 7.45, $p<.0005$ for attitudinal loyalty; $\beta=.32, t=3.92, p<.001$ and $\beta=.41, t=4.62, p<$ .0005 for behavioural loyalty. When splitting the sample into two groups, namely VIP and non-VIP gamblers based on their reported average betting volume - the criterion that is commonly adopted by casinos, CASERV explained significant variance in attitudinal loyalty in both cases $\left(\mathrm{R}^{2}=38 ; 32\right.$ respectively, $\left.\mathrm{p}<.0005\right)$; however, the portion of variance in behavioural loyalty was insignificant in the latter case.

Insert Table 2 about here

To understand how customers perceive casino service quality and how their perceptions affect loyalty, the researchers undertook one-way between-group analyses of variance (ANOVA) by separating the respondents into three groups: LFVs, MFVs and HFVs. 
The results indicate that there were statistically significant differences in the overall service quality scores across the three groups at $p<.05$ level. Using an eta squared calculation, the applicable effect size was .08, which is substantial on the basis of Cohen's (1988) guidelines for eta squared. Post-hoc comparisons using the Turkey HSD test indicated that the mean score for LFVs $(M=42.57, S D=5.58)$ differed significantly from what was reported for the MFVs $(M=48.12, S D=5.23)$ and HFVs $(M=48.38, S D=5.98)$. When analysing customer perceptions of each of the CASERV dimensions, significant differences were only evident for customers from different groups on the basis of mean scores in the case of Service Delivery; and the effective size was .09. The Turkey HSD analysis demonstrates a large gap between the mean scores for the LFVs and the HFVs and MFVs. When the same analysis was used to compare the mean scores for each group on the basis of attitudinal loyalty, substantial intergroup differentials were evident. As is summarised in Table 3, the MFVs and LFVs generally reported higher scores than the HFVs, indicative of positive attitudes towards the casino.

Insert Table 3 about here

\section{Discussion and conclusions}

It has been a long established view that service quality is a key determinant of casino sustainability and competitive advantage. In addressing this claim the present paper has provided insights into the relationship between service quality and customer loyalty which was operationalized into attitudinal and behavioural dimensions. The researchers surveyed gaming-focused customers from segments that are classified on the basis of visiting frequency using a quantitative method. The findings have particular implications for casinos within Asia that are seeking to gain competitive advantage and maintain their profitability in an increasingly competitive market environment. The study has proposed guidelines for the enhancement of casino service provision and has identified where such improvements are most needed.

The results indicate that CASERV has shown that service quality explains significant variance in customer loyalty. In particular, Service environment and service delivery make substantial contributions to both attitudinal and behavioural loyalty. The former is an indicator of the casino facilities and atmosphere, whereas the latter concerns the interactions between casino customers and service representatives, especially in the case of casino hosts. 
The results reflect the importance of casino frontline employees for managing customer relationships and for determining service quality. However, when analysing this relationship separately for VIP and non-VIP players, service quality has minimal influence on the behavioural loyalty of the latter group. These findings have the following implications.

Although service quality is commonly regarded as an important determinant of customer loyalty, it does not constitute the totality of a customer's judgement about an entity's overall excellence or superiority. The various service encounters experienced by customers result in differing perceptions and attitudes. An overall assessment of service quality comprises a combination of perceptions arising from each service encounter between the customer and the service provider (in this case the casinos). If customers are to develop positive perceptions of an organization's provision of quality service, the service encounter will need to be closely managed. Since the various dimensions of service quality have differential impacts on customer loyalty, and casino managers are concerned with cost effectiveness and resource utilisation, they should focus on the aspects that most concern the loyalty and retention of particular groups. Their intention to return is influenced primarily by interactions and the relationships that they develop with frontline employees. With a view to enhancing customer loyalty and retention, it will be essential to provide opportunities for building ongoing rapport between the casino employees and guests (Gremler \& Gwinner, 2000). It is also imperative to provide relevant training for employees who have contact with players. On the other hand, it is probable that despite gamblers' apparent indifference towards tangible offerings, they would complain at any withdrawal of these services; or they might be enticed by other casinos. It is suggested that casino managers should give thorough attention to this dilemma and ensure that resources are used efficiently with a view to maximising revenues.

The finding that service quality explained significant variance in the attitudinal loyalty of non-VIP or low-end players, but not their behavioural loyalty has important implications for casino managers. Although these players contribute relatively less to gaming revenues, they make casinos look good and often participate in other activities within the casino premises (see Watson \& Kale, 2003). It provides a cautionary note to casinos that service quality is important in attracting player patronage and behavioural intentions. Actual patronage (or behavioural loyalty) is affected when service quality is perceived favourably. On the other hand, although frequency of visit and betting volume are indicative of the loyalty of casino customers, the practice should not imply prejudice or discrimination towards low-end volume and LFV clients. Such an implication risks influencing customer 
perceptions of service quality. Defined as overall judgements about an entity's overall service excellence, service quality may also be viewed as a comparison of services that customers expect from the provider with their perceptions of service performance. Although their expectations may be optimised, it is unsurprising and logical that players in different groups expect differential levels of service. Casinos would be well advised to manage player expectations and make appropriate adjustments based on their level of loyalty. Furthermore, it may be advisable for casinos to provide more non-gaming facilities for enticing non-VIP players' patronage.

In proposing opportunities for further research a number of limitations of the study should be acknowledged. First, the gathering of survey results from a single location may limit the capacity to generalise the findings. Second, although CASERV is a reliable and valid scale for measuring casino service quality, future research should employ other service quality scales such as SERVQUAL in combination of CASERV to gain a better understanding of the casino service quality - customer loyalty relationship. 


\section{References}

Bitner, M. J., and Hubbert, A. R. (1994). "Encounter satisfaction versus overall satisfaction versus quality". In Rust, R.T. and Oliver, R.C. (eds) Service quality: New directions in theory and practice, pp 72-94 Sage, Thousand Oaks, California .

Brady, M.K, and Cronin, J.J. (2001). "Some new thoughts on conceptualising perceived service quality: a hierarchical approach". Journal of Marketing. 65(3), 34-49

Chandon, J. L., Leo, P. Y., and Philippe, J. (1997). "Service encounter dimensions-a dyadic perspective: Measuring the dimensions of service encounters as perceived by customers and personnel”. International Journal of Service Industry Management, $8(1), 65-86$.

Cronin, J. J., and Taylor, S. A. (1992). "Measuring service quality: a re-examination and extension". Journal of Marketing, 56(3), 55-68.

Dick, A. and Basu, K., 1994. "Customer loyalty: towards an integrated framework". Journal of the Academy of Marketing Science 22 (2), 99-113.

Ennew, C. T., and Binks, M. R. (1996). “The Impact of Service Quality and Service Characteristics on Customer Retention: Small Businesses and their Banks in the UK". British Journal of Management, 7(3), 219-230.

Gremler, D. D., and Gwinner, K. P. (2000). "Customer-employee rapport in service relationships". Journal of Service Research, 3(1), 82-104.

Gronroos, C. (1984). "A service quality model and its marketing implications". European Journal of Marketing. 18(40), 36-44

$\mathrm{Gu}, \mathrm{Z}$., Siu, R.C.S. (2008). "Industry labour force quality: an investigation from the customer service perspective". UNLV Gaming Research and Review Journal. 12 (1/2), 1-13

Hallowell, R. (1996). "The relationships of customer satisfaction, customer loyalty, and profitability: an empirical study". International Journal of Service Industry Management, 7(4), 27-42

Heskett, J. L., Jones, T. O., Loveman, G. W., Sasser, W., and Schlesinger, L. A. (2008). "Putting the service-product chain to work". Harvard Business Review, 72(2), 164174.

Kale, S. H., and Klugsberger, P. (2007). "Reaping rewards" [Electronic Version]. Marketing Management, 16(4), 14-18.

Kale, S.H. (2005). "Optimally managing casino high-end market”. Bright Ideas, www.urbino.net

Klebanow, A.M. (2002). "Developing the casino marketing plan". UNLA Gaming Research and Review Journal. 6(2), 63-71.

Kumar,V. and Denish Shah (2004), "Building and Sustaining Profitable Customer Loyalty for the 21 st Century," Journal of Retailing, 80 (4), 317-30.

Lam, D. (2010). No more "take it or leave it" service mentality in Macau. Macau Daily Times. 29 Sep, 2010. http://www.macaudailytimes.com.mo/opinion/17403-moretake-leave-service-mentality-Macau.html

Liljander, V., and Strandvik, T. (1995). "The nature of customer relationships in services". Advances in services marketing and management, 4, 141-167.

Lucas, A.F. (2003). "The determinants and effects of slot servicescape satisfaction in a Las Vegas hotel casino". UNLV Gaming Research and Review Journal. 7(1), 1-19

McCaina, S. L., Jang, S.C., and Hu, C. (2005). "Service quality gap analysis toward customer loyalty: practical guidelines for casino hotels". Hospitality Management, 24, 465-472.

MacDonald, A. (2002). "Dealing with high-rollers". Urbino. Net/articles.

Oliver, R. L. (1993). "Cognitive, affective, and attribute bases of the satisfaction response". The Journal of Consumer Research, 20(3), 418-430. 
Parasuraman, A., Zeithaml, V. A., and Berry, L. L. (1988). "SERVQUAL: A Multiple-Item Scale for Measuring Consumer Perceptions of Service Quality". Journal of Retailing 64(1), 12-40

Parasuraman, A., Zeithaml, V. A., and Berry, L. L. (1994). "Reassessment of expectations as a comparison standard in measuring service quality: Implications". Journal of Marketing 58(1), 111-124 Rust,

Prentice, C, King, B., \& Ohtsuka, K. (2012). Service quality, tiered customer segments and casino player retention. Services Marketing Quarterly.

http://www.tandfonline.com/doi/abs/10.1080/15332969.2012.714700

Rust, R. T., and Zaborik, A. J. (1993). "Customer Satisfaction, Customer Retention, and Market Share", Journal of Retailing 69(2), 193-215

Storbacka, K., Strandvik, T., and Grönroos, C. (1994). "Managing customer relationships for profit: the dynamics of relationship quality". International Journal of Service Industry Management, 5(5), 21-38.

Strauss, A.L., and Corbin, J. (1990). Basics of qualitative research: grounded theory procedures and techniques. Sage, Newbury Park, California

Stutz, H. (2009). Serve customer, service yourself. 26(20). Las Vegas Business Press (10712186), p 14.

Suh, E., Erdem, M. (2009). "Gap analysis as a diagnostic tool for improving the slot gaming experience". Journal of Hospitality Marketing and Management 18(4), 445-455

Watson, L., and Kale, S. H. (2003). "Know when to hold them: Applying the customer lifetime value concept to casino table gaming”. International Gambling Studies, 3(1), 89-101.

Wong, I. A., and Fong, V. H. I. (2010). "Examining casino service quality in the Asian Las Vegas: An alternative approach". Journal of Hospitality Marketing and Management, $19(8), 842-865$.

Woodside, A. G., Frey, L. L., and Daly, R. T. (1989). "Linking service quality, customer satisfaction, and behavioural intention". Journal of Health Care Marketing, 9(4), 5

Zeithaml, V. A., Berry, L. L., and Parasuraman, A. (1996). "The behavioural consequences of service quality". Journal of Marketing, 60(2), 31-46

Zeithaml, V. A., Rust, R. T., and Lemon, K. N. (2001). "The customer pyramid: creating and serving profitable customers". California Management Review, 43(4), 118-142 


\section{Table 1}

Cronbach alpha values, correlation coefficients, means and standard deviations of the CASERV scale and customer attitudinal loyalty

\begin{tabular}{lccccccc}
\hline & $\alpha$ & Means & SD & 1 & 2 & 3 & 4 \\
\hline & & & & & & & \\
1. Game service & .75 & 3.41 & 0.61 & & & & \\
2. Service environment & .74 & 3.67 & 0.67 & $.32^{*}$ & & & \\
3. Service delivery & .89 & 3.29 & 0.57 & $.45^{* *}$ & $.44^{* *}$ & & \\
4. Food service & .72 & 3.21 & 0.66 & $.40^{* *}$ & $.40^{* *}$ & $.55^{* *}$ & \\
5. attitudinal loyalty & .81 & 3.38 & 0.72 & .20 & $.36^{*}$ & $.50^{* *}$ & .21 \\
\hline
\end{tabular}

Note: $* \mathrm{p}<.01, * * \mathrm{p}<.001$ 
Table 2

Multiple Regression Analyses of CASERV dimensions as predictors of customer loyalty

\begin{tabular}{ccccccc}
\hline Predictor & \multicolumn{5}{c}{ Coefficients } \\
\hline & $\mathrm{AL}$ & $\mathrm{BL}$ & $\mathrm{AL}$ & $\mathrm{BL}$ & $\mathrm{AL}$ & $\mathrm{BL}$ \\
& & \multicolumn{7}{c}{ VIP players } & Non-VIP players \\
& $\mathrm{R}^{2}=.42^{* * *}$ & $\mathrm{R}^{2}=.34^{* * *}$ & $\mathrm{R}^{2}=.38^{* * *}$ & $\mathrm{R}^{2}=.32^{* * *}$ & $\mathrm{R}^{2}=.33^{* * *}$ & $\mathrm{R}^{2}=.16$ \\
$\mathrm{GS}$ & .11 & .09 & .06 & .08 & .13 & .07 \\
$\mathrm{SE}$ & $.32^{* *}$ & $.32^{* *}$ & $.26^{*}$ & $.29 *$ & $.24 *$ & .16 \\
$\mathrm{FS}$ & .14 & .09 & .11 & .11 & .14 & .13 \\
$\mathrm{SD}$ & $.46^{* * *}$ & $.41^{* * *}$ & $.37 * * *$ & $.46^{* * *}$ & $.19 *$ & .16 \\
\hline
\end{tabular}

Note: $* \mathrm{p}<.05, * * \mathrm{p}<.001 ; * * * \mathrm{p}<.0005$

$\mathrm{AL}=$ attitudinal loyalty, $\mathrm{BL}=$ behavioural loyalty, $\mathrm{GS}=$ game service, $\mathrm{SE}=$ service environment, $\mathrm{FS}=$ food service, $\mathrm{SD}=$ service delivery. 


\section{Table 3}

ANOVAs for the relationship between customer segments, attitudinal loyalty and perceptions of service quality

\begin{tabular}{|c|c|c|c|c|c|c|}
\hline & $\mathrm{N}$ & Mean & SD & $\mathrm{df}$ & $\mathrm{F}$ & Sig. \\
\hline CASERV & $\begin{array}{l}\text { LFVs } \\
\text { MFVs } \\
\text { HFVs }\end{array}$ & $\begin{array}{l}42.57 \\
48.12 \\
48.38\end{array}$ & $\begin{array}{l}5.58 \\
5.23 \\
5.98\end{array}$ & $(4,292)$ & 4.17 & .02 \\
\hline $\begin{array}{l}\text { Game } \\
\text { service }\end{array}$ & $\begin{array}{l}\text { LFVs } \\
\text { MFVs } \\
\text { HFVs }\end{array}$ & $\begin{array}{l}11.78 \\
12.89 \\
13.01\end{array}$ & $\begin{array}{l}1.67 \\
1.76 \\
1.82\end{array}$ & $(4,292)$ & 1.48 & .10 \\
\hline $\begin{array}{l}\text { Service } \\
\text { environment }\end{array}$ & $\begin{array}{l}\text { LFVs } \\
\text { MFVs } \\
\text { HFVs }\end{array}$ & $\begin{array}{l}11.01 \\
12.23 \\
13.76\end{array}$ & $\begin{array}{l}1.89 \\
1.97 \\
2.13\end{array}$ & $(4,292)$ & 1.79 & .06 \\
\hline $\begin{array}{l}\text { Food } \\
\text { service }\end{array}$ & $\begin{array}{l}\text { LFVs } \\
\text { MFVs } \\
\text { HFVs }\end{array}$ & $\begin{array}{l}11.79 \\
12.91 \\
13.01\end{array}$ & $\begin{array}{l}1.98 \\
1.85 \\
2.03\end{array}$ & $(4,292)$ & 1.71 & .07 \\
\hline $\begin{array}{l}\text { Service } \\
\text { delivery }\end{array}$ & $\begin{array}{l}\text { LFVs } \\
\text { MFVs } \\
\text { HFVs }\end{array}$ & $\begin{array}{l}8.79 \\
13.72 \\
12.51\end{array}$ & $\begin{array}{l}1.71 \\
1.98 \\
2.11\end{array}$ & $(4,292)$ & 4.26 & .001 \\
\hline $\begin{array}{l}\text { Attitudinal } \\
\text { loyalty }\end{array}$ & $\begin{array}{l}\text { LFVs } \\
\text { MFVs } \\
\text { HFVs }\end{array}$ & $\begin{array}{l}17.21 \\
14.35 \\
22.12\end{array}$ & $\begin{array}{l}1.56 \\
2.28 \\
2.31\end{array}$ & $(4,292)$ & 4.95 & .001 \\
\hline
\end{tabular}

Note: $\mathrm{N}=98$ for LFVs, $\mathrm{N}=101$ for MFVs, $\mathrm{N}=105$ for HFVs 